\title{
Midazolam-sirupus, formulation and pharmacodynamic efficacy
}

\author{
K. Goracinova ${ }^{1 *}$, K. Mladenovska ${ }^{1}$, O. Gelevska ${ }^{1}$, E. Fredro-Kumbaradzi ${ }^{1}$, \\ M. Glavaš-Dodov ${ }^{1}$, J. Nanceva ${ }^{2}$ \\ ${ }^{1}$ Institute of Pharmaceutical Technology, Department of Biopharmacy, Faculty of Pharmacy, \\ SS Cyril and Methodius University, Vodnjanska 17, 1000 Skopje, Republic of Macedonia \\ ${ }^{2}$ Clinic for Orthopedic Diseases, Clinical Center at the Faculty of Medicine, SS Cyril and Methodius University, \\ Vodnjanska 17, 1000 Skopje, Republic of Macedonia
}

Received November 2001; accepted March 2002

\begin{abstract}
Due to its pharmacokinetic and pharmacodynamic properties (sedation, amnesia and relief of anxiety) Midazolam has become a commonly used agent for conscious sedation of children before diagnostic or therapeutic procedure or before induction of anesthesia. Considering the advantage of oral administration to avoid the additional trauma of starting an IV in the child, and the fact that there is no adequate dosage form (Midazolam - Syrupus) on the drug market in our country, the aim of the presented work was to formulate syrupus using syrupus base/aqueous solution of viscosity enhancer - HPMC, in combination with suitable sweetener, flavor, and preservatives, and to evaluate its quality and stability. The pharmacodynamic efficacy/sedative effect of Midazolam $\mathrm{HCl}$ - Syrupus formulation was evaluated in 33 pediatric patients comparing this with the efficacy of intramuscularly administered Midazolam $\mathrm{HCl}$ (35 pediatric patients) in accordance with the Ramsay scale for analgosedation.

The formulation manifested good quality in respect to physical properties, physico-chemical parameters ( $\mathrm{pH}$ value, relative density, drug content, ingredients content) antimicrobial efficacy and microbiological quality according to Ph Eur 3. In the conditions characteristic of the second (II) climate zone, the dosage form was stable for four months. The sedative effect of orally administered Midazolam was manifested in a period necessary for surgical premedication (30 - $45 \mathrm{~min}$ ). The majority of patients (71\%) entered the second phase on the Ramsay scale, when Midazolam was administered in a dose of $0.40 \mathrm{mg} / \mathrm{kg}$.
\end{abstract}

Key words: Midazolam, syrupus, formulation, quality control, sedative efficacy

\section{Introduction}

Anxiolysis with drugs and psychoprophylaxis are both recognized methods of preoperative preparation. Benzodiazepine Diazepam is used for sedation. However, the short-acting benzodiazepine Midazolam has potential advantages over Diazepam. Due to its unique chemical structure (1,4-benzodiazepine derivative) depending on environmental $\mathrm{pH}$, the drug can produce highly water-soluble salts ( $\mathrm{pH}$ less than 4) or exist in lipophylic diazepine ring-closed form ( $\mathrm{pH}$ greater than 4). The $\mathrm{pH}$ dependence of the opening or closure of a ring in Midazolam's

*katerina.goracinova@baba.ff.ukim.edu.mk phone. + 38902126 032; 119 694; fax: + 38902123054 molecular structure suggests a pH dependence of the mucosal absorption. Thus, a significant amount of orally administered Midazolam may be absorbed by the mucosal membranes in the oral cavity, esophagus, and the stomach (1). This contributes to a rapid onset of action and to good clinical tolerance. After both oral and intramuscular administration, Midazolam has a fast absorption rate and is rapidly excreted, with a half-life of only about 2 hours. A reasonably good correlation has been found between plasma levels and clinical effects, indicating a fast, but brief response. In anesthesiology, Midazolam appears to be a useful, short-acting, sedative-anxiolytic and amnesic premedication after both oral and parenteral administration. Its advantages include good cardiovascular stability, transient and mild respiratory depression, low frequency of venous irritation, 
production of anterograde amnesia and short duration of action in comparison with other benzodiazepines (2 - 3).

Until recently, only the intravenous form of the drug was available. Environment or frightened parents together with additional trauma of starting an IV in the child were overwhelming for the child. Many practitioners used the IV preparation for oral administration to avoid the additional trauma. However, the liquid was very bitter even with added flavoring. So, one of the methods of reducing anxiety for a pediatric patient was oral Midazolam (4).

A comparative study of heart rate (HR), blood pressure (BP) and norepinephrine, epinephrine and cortisol levels in two groups of children, one receiving psychological treatment only, and the other receiving $0.2 \mathrm{mg} / \mathrm{kg}$ Midazolam orally, showed that HR, BP, as well as humoral stress parameters indicate that Midazolam in a recommended dose is sufficient to reduce preoperative stress in children (5). Comparing the preoperative sedative effects and the postoperative recovery profiles of two oral premedicants: Midazolam $(0.5 \mathrm{mg} / \mathrm{kg})$ and a combination $0.2 \mathrm{ml} / \mathrm{kg}$ of Meperidine $(6 \mathrm{mg} / \mathrm{ml})$, Atropine $(0.08 \mathrm{mg} / \mathrm{ml})$, and Diazepam $(0.6 \mathrm{mg} / \mathrm{ml})$, it was concluded that the majority of children in both groups achieved acceptable separation and induction scores. However, the Midazolam subjects showed significantly better improvement in scores at both separation and induction (6).

The research activities of Tolksdarf, Eick and Riva et al. (7 - 8) considering the efficacy of Midazolam administered rectally, orally and nasally in pediatric patients confirmed that oral administration is well accepted and more effective than other ways of administration. Special consideration should be taken only in respect to the adverse effects. The nasal administration of Midazolam should be avoided as a routine in premedication of pediatric patients because of legal acceptability.

In November 1998, the FDA approved Versed Syrup, a flavored liquid that contains an artificial bitterness modifier. Syrup is indicated for use in pediatric patients for sedation, anxiolysis and amnesia prior to diagnostic, therapeutic or endoscopic procedures or before induction in anesthesia. The recommended dose for children is a single dose of 0.25 to 0.5 $\mathrm{mg} / \mathrm{kg}$ to a maximum dose of $20 \mathrm{mg}$. Younger children (6 months to less than 6 years) and less cooperative children may require a higher dose of up to $1 \mathrm{mg} / \mathrm{kg}$. In obese children the dose should be calculated based on ideal body weight. The dose should be individualized for the patient's age, level of anxiety and medical need. The time of onset is usually within 10 to 20 minutes. The relationship between plasma concentration and sedation and anxiolysis scores of oral Midazolam syrup (single oral doses from $0.25-1.0 \mathrm{mg} / \mathrm{kg}$ ) in three age groups (6 months to $<2$ yrs, 2 to $<12$ yrs, and 12 to $<16$ yrs) showed that the mean Midazolam plasma concentration as well as the mean of Midazolam plus alpha - hydroxymidazolam (pharmacologically active metabolite) plasma concentration for those patients with a sedation score of 4 (asleep but responsive to mild shaking) is significantly different from the mean concentrations for those with a sedation score of 3 (drowsy), which is significantly different from the mean concentrations for patients with a sedation score of 2 (awake/calm). The statistical analysis indicated that the greater the Midazolam, or Midazolam plus alpha-hydroxymidazolam concentration, the greater the sedation score for pediatric patients. No such trend was observed in anxiolysis, which is a more variable surrogate measurement of clinical response.

Several investigators have worked on formulation and stability evaluation of Midazolam-Syrupus using Midazolam for IV administration. Steedman and co-workers (9) have researched the stability of a peroral solution of Midazolam prepared from IV taste-modified Midazolam formulation and stored at different temperatures. All the examined parameters (physical, physico-chemical, microbiological, drug content) showed stability at a decreased and increased temperature. A similar formulation prepared by Walker et al. (10) showed stability over 102 days under similar conditions.

Considering the advantages of Midazolam and of oral administration in the form of syrup, also, and the fact that no such formulation is available on the market in our country, as an aim of the study we formulate Midazolam Syrupus using a contemporary approach in designing the syrup preparations. In other words, an aqueous solution of hydroxypropyl methylcellulose was used as a syrup base due to its adequate viscosity. The characterization of the formulation includes physical and physico-chemical parameters, microbiological quality and the antimicrobial efficacy of the preservative used. The stability of the formulation was also periodically evaluated through the physical and physico-chemical parameters and microbiological quality. The effectiveness of this formulation as a premedicant to sedate and calm pediatric patients prior to induction of general anesthesia was evaluated in a randomized, double-blind, parallel-group study comparing an other group, in which Midazolam was intramuscularly administered.

\section{Materials and methods}

\section{Materials}

The following materials were supplied from commercial sources: Midazolam (Roche, USA), Sodium benzoas p.a. (Alkaloid, Macedonia), Saccharin Sodium (Merck, Germany), Hydroxypropyl methylcellulose (HPMC)-Metocel E15 (Hercules, USA). 


\section{Midazolam-Syrupus formulation}

The contemporary approach in formulating the syrup includes the following materials and steps:

\begin{tabular}{lc} 
Midazolam & 0.10 \\
Sodium benzoas & 0.22 \\
Saccharin Sodium & 0.18 \\
Flavor-banana & 0.10 \\
HPMC (aqueous sol. 3\% w/V) & ad \\
\hline
\end{tabular}

Midazolam is solubilized in an aqueous medium with a presence of $0.1 \mathrm{~mol} / \mathrm{L} \mathrm{HCl}$ to form a solution in which each $\mathrm{ml}$ contains Midazolam $\mathrm{HCl}$ equivalent to $1 \mathrm{mg}$ Midazolam. The presence of $0.1 \mathrm{~mol} / \mathrm{L} \mathrm{HCl}$ induces acidity in a range of 3.90 - 3.95 in which an equilibrium between diazepine ring -closed and ring-opened form exists (reversible forming) due to the acid catalyzed opening of 4,5 double force of diazepine ring. Bioavailability studies (1) of commercially available Midazolam syrupus for oral administration with a $\mathrm{pH}$ of 2.8 to 3 suggest that the absorption from the syrup may be significantly improved by slightly increasing the $\mathrm{pH}$. In a physiological $\mathrm{pH}$ open-ring form transforms into physiologically active lypophilic closed-ring form.

Such a solution, together with Sodium benzoas, Saccharin Sodium and flavor are added to a previously prepared aqueous solution of HPMC ( $3 \% \mathrm{w} / \mathrm{V})$. Sodium benzoas as a preservative is active in a $\mathrm{pH}$ range of 2 - 5.

\section{Physico-chemical characterization}

\section{of Midazolam-Syrupus}

Physical properties, such as color, odor, taste and transparency were tested. For determining the color changes semiquantitative analysis was performed using spectrophotometry in visible wavelength.

$\mathrm{pH}$ value was determined according to the method proposed by Ph. Eur. 3 (potentiometric determination, pH meter MA 5705, Iskra-Kranj).

The viscosity was determined using a Brookfield rotating viscometer, according to the method proposed by Ph. Eur. 3 (50 rpm Brookfield model P1.2M. 2010 Shanon Ireland).

The relative density was also determined according to the method proposed by Ph. Eur. 3 (pycnometric).

\section{Drug content in Midazolam-Syrupus}

Midazolam content was determined using the HPLC technique (Perkin Elmer, pump: Serie 200LC, auto sampler: ISS200, Detector: 785A UV/VIS) with acetonitrile and bufferpotassium dihydrogen phosphate (70:30) as mobile phase (2.0 $\mathrm{ml} / \mathrm{min}$ at $35^{\circ} \mathrm{C}$ and $275 \mathrm{~nm}$ for Midazolam). The contents of other ingredients, such as Sodium Benzoas and Saccharin Sodium, were also determined using the same technique.

\section{Microbiological analysis of Midazolam-Syrupus}

The method proposed in Ph. Eur. 3 for the microbiological quality of a non-sterile preparation was used in determining the microbiological quality of Midazolam Syrupus formulation. Adequate microbiological methods were used for the detection and quantifying of the following bacteria: Salmonella, Pseudomonas aeruginosa, Escherichia coli, Staphylococcus aureus, fungus and mold. According to the Ph. Eur. 3 regulations, $1 \mathrm{ml}$ of the sample may contain $10^{4}$ aerobic bacteria, $10^{2}$ fungus and $10^{2}$ other enterobacteria. The presence of the above-mentioned bacteria is not allowed.

\section{Antimicrobial efficacy of the preservative, Sodium}

benzoate, used in Midazolam-Syrupus formulation

The evaluation of antimicrobial efficacy of the preservative was made according to the method proposed by Ph. Eur. 3 using standard inoculums of separate suspensions of Pseudomonas aeruginosa and Candida albicans $\left(10^{8} / \mathrm{ml}\right.$ micro-organisms according to the Mc Farland standard). $10 \mathrm{ml}$ of the preparation were inoculated with $0.1 \mathrm{ml}$ bacterial suspension and the number of microorganisms was counted in blood-agar medium over a period of 14 and 28 days.

\section{Stability evaluation of Midazolam Syrupus}

Stability evaluation was performed by maintaining the formulation at temperatures of $2-8{ }^{\circ} \mathrm{C}$ and $26+0.5^{\circ} \mathrm{C}$ over a period of 4 months, while at $37{ }^{\circ} \mathrm{C}$ the preparation was maintained over a period of one month. Physical and physico -chemical parameters, drug content, ingredients contents and the microbiological quality were determined periodically in the $1^{\text {st }}, 3^{\text {rd }}$ and $4^{\text {th }}$ month of syrup preparation.

\section{Sedative efficacy of Midazolam-Syrupus}

The dynamic and quality of sedation of Midazolam (intramuscularly and perorally administered) were investigated in 68 children (ASA Physical Status 1 and 2; aged 1 - 13 yrs) submitted to orthopedic operative treatment at the Clinic for Orthopedic Disease at the Clinical Center in Skopje. The first group of 35 children (Group 1) was treated with Midazolam intramuscularly administered in a dose of $0.15-0.2 \mathrm{mg} / \mathrm{kg}$, while to the second group of 33 children (Group 2) Midazolam was administered perorally in a form of prepared syrup and in a dose of $0.4 \mathrm{mg} / \mathrm{kg}$.

The sedative efficacy was followed according to the Ramsay scale of analgosedation (1. frightened, agitated; 2. slightly sedated, oriented; 3. response to commands only; 4. prompt response to slight stimulation; 5 . delayed response to slight 
stimulation; 6. no response to stimulation) within 10, 20, and 30 minutes of administration considering the time necessary for preoperative treatment (30 - 45 minutes).

\section{Results and discussion}

The Midazolam-Syrupus prepared is a clear, colorless, banana flavored liquid that contains Saccharin Sodium as an artificial bitterness modifier. The Syrupus contains $1 \mathrm{mg}$ Midazolam per 1 $\mathrm{ml}$. The results conserning the physico-chemical parameters at the time of preparing the formulation are presented in Table 1.

In respect to the microbiological quality and preservative activity of Sodium benzoate the formulation is in accordance to the standards proposed by the Ph. Eur. 3. The formulation prepared contains less than $10^{4}$ aerobic bacteria, $10^{2}$ fungus and $10^{2}$ other enterobacteria. The presence of Salmonella, Pseudomonas aeruginosa, Escherichia coli, Staphylococcus aureus was not registered.

The criterion of acceptance of the preservative efficacy was the reduction of living microorganisms (log value) regarding their total number in inoculums. The following log values are adequate for the microorganisms of interest according to the Ph. Eur. 3 (3 for bacteria and 1 for fungus during 14 days without increase in their growth during the 28 days). Considering the Midazolam-Syrupus formulation, the criteria for the success of preservative used, Sodium benzoate, were satisfied.

There were no changes in the physical properties of the Midazolam-Syrupus over the 4 months at the temperatures investigated; 2 - $8{ }^{\circ} \mathrm{C}$ and $26+0.5^{\circ} \mathrm{C}$. The physical status of the formulation was not changed, either, after 1 month of maintaining at $37{ }^{\circ} \mathrm{C}$. Due to the instability of flavor under the conditions of the stability test, its evaluation was performed at room temperature.

As Table 2 shows there are no significant changes in the physico-chemical properties of the Midazolam-Syrupus formulation in a period of 1 month after maintaining the formulation at $2-8^{\circ} \mathrm{C}$ and $26+0.5^{\circ} \mathrm{C}$. There are not any changes in the microbiological quality of this preparation, either, in the same period at all temperatures investigated. By maintaining the formulation at a temperature of $37^{\circ} \mathrm{C}$, significant changes in Midazolam $\mathrm{HCl}$ content can be observed in the same period of study. This indicates the necessity of providing the conditions for maintaining the quality of the preparation if the temperature deviates from the middle temperature for the $2^{\text {nd }}$ climate zone $\left(25^{\circ} \mathrm{C}\right)$.

As Table 3 indicates there are not any significant changes in the physico-chemical properties of the Midazolam-Syrupus formulation after 4 months of studies after maintaining the formulation over a period of 4 months at $2-8^{\circ} \mathrm{C}$ and $26+0.5$

Table 1. Physico-chemical parameters of Midazolam-Syrupus formulation

\begin{tabular}{lc}
\hline \hline Physico-chemical parameter & $\begin{array}{c}\text { Midazolam -Syrupus } \\
\pm \mathrm{SD}(\mathrm{n}=3)\end{array}$ \\
\hline $\mathrm{pH}$ & $3.96 \pm 0.06$ \\
Relative density $\left(\mathrm{kg} / \mathrm{m}^{3}\right)$ & $1.00 \pm 0.03$ \\
Viscosity $(\mathrm{mPa} \cdot \mathrm{s})$ & $38.00 \pm 0.07$ \\
Midazolam content $(\%)$ & $101.30 \pm 0.07$ \\
Sodium Benzoas content $(\%)$ & $99.80 \pm 0.05$ \\
Saccharin Sodium content $(\%)$ & $100.00 \pm 0.08$ \\
\hline
\end{tabular}

${ }^{\circ} \mathrm{C}$. The microbiological quality of the formulation was also in accordance to the standards proposed by the Ph. Eur. 3 .

The majority of patients receiving Midazolam in the form of Syrupus entered the $2^{\text {nd }}$ phase of the Ramsay scale in a period of 20 - 30 minutes, by which the basic principles of surgical premedications are fulfilled. Although intramuscular application causes faster (15 - 20 minutes) and more intensive clinical response (percent of patients entering the $2^{\text {nd }}$ phase of the Ramsay scale is higher; 80 vs. $71 \%$ ), oral premedication can successfully replace intramuscular administration (Fig. 1). Considering the percentage of patients, who did not enter the second phase of the Ramsay scale (20\% in Group 1, and $29 \%$ in Group 2) it can be concluded that the quality and dynamic of sedative efficacy are strictly individual and depend on the general condition of the patient and level of anxiety, which is especially emphasized in pediatric patients.

Table 2. Physico-chemical parameters of Midazolam-Syrupus formulation after 1 month of stability studies

\begin{tabular}{|c|c|c|c|}
\hline \multirow[t]{2}{*}{ Physico-chemical parameter } & \multicolumn{3}{|c|}{$\begin{array}{l}\text { Measured parameters of different temperature } \\
\text { of storage of Midazolam-Syrupus } \pm \text { SD }(n=3)\end{array}$} \\
\hline & $2-8{ }^{0} \mathrm{C}$ & $26 \pm 0.5^{0} \mathrm{C}$ & $37{ }^{0} \mathrm{C}$ \\
\hline $\mathrm{pH}$ & $3.95 \pm 0.04$ & $3.94 \pm 0.05$ & $3.96 \pm 0.05$ \\
\hline Relative density $\left(\mathrm{kg} / \mathrm{m}^{3}\right)$ & $1.00 \pm 0.05$ & $1.00 \pm 0.05$ & $1.00 \pm 0.07$ \\
\hline Viscosity (mPa $\cdot \mathrm{s})$ & $38.00 \pm 0.08$ & $38.00 \pm 0.07$ & $38.00 \pm 0.06$ \\
\hline Midazolam content (\%) & $100.00 \pm 0.07$ & $101.30 \pm 0.08$ & $86.00 \pm 0.06$ \\
\hline Sodium Benzoas content (\%) & $99.70 \pm 0.05$ & $98.98 \pm 0.06$ & $99.00 \pm 0.08$ \\
\hline Saccharin Sodium content (\%) & $98.85 \pm 0.08$ & $98.85 \pm 0.08$ & $98.93 \pm 0.09$ \\
\hline
\end{tabular}


Table 3. Physico-chemical parameters of Midazolam-Syrupus formulation after 4 months of stability studies

\begin{tabular}{|c|c|c|}
\hline \multirow{2}{*}{ Physico-chemical parameter } & \multicolumn{2}{|c|}{$\begin{array}{l}\text { Measured parameters of different temperature } \\
\text { of storage of Midazolam-Syrupus } \pm \text { SD }(n=3)\end{array}$} \\
\hline & $2-8{ }^{0} \mathrm{C}$ & $26 \pm 0.5{ }^{0} \mathrm{C}$ \\
\hline $\mathrm{PH}$ & $3.96 \pm 0.04$ & $3.99 \pm 0.05$ \\
\hline Relative density $\left(\mathrm{kg} / \mathrm{m}^{3}\right)$ & $1.00 \pm 0.06$ & $1.00 \pm 0.05$ \\
\hline Viscosity $(\mathrm{mPa} \cdot \mathrm{s})$ & $38.00 \pm 0.07$ & $38.00 \pm 0.06$ \\
\hline Midazolam content (\%) & $99.30 \pm 0.09$ & $98.38 \pm 0.08$ \\
\hline Sodium Benzoas content (\%) & $98.30 \pm 0.05$ & $99.00 \pm 0.06$ \\
\hline Saccharin Sodium content (\%) & $93.36 \pm 0.08$ & $98.81 \pm 0.07$ \\
\hline
\end{tabular}

No adverse effects, such as respiratory depression, airway obstruction, oxygen desaturation or apnea occurred during the clinical study with Midazolam- Syrupus at the dose administered.

\section{Conclusion}

The Midazolam-Syrupus formulation manifested good quality in respect to physical and physico-chemical parameters (pH value, relative density, drug content, ingredients content), antimicrobial efficacy and microbiological quality according to Ph. Eur. 3. In the conditions characteristic of the second (II) climate zone, the dosage form was evaluated over 4 months and maintained stability during this period of study. If the temperature deviates from the middle temperature of the second (II) climate zone it is necessary for adequate storage conditions to be provided.

Oral premedication can successfully replace intramuscularly administration in pediatric patients; special consideration should be taken in respect to the general condition of the patient and the level of anxiety; thus the doses should be individually adjusted. The recommended dose is in a range of 0.25 to $1.0 \mathrm{mg} / \mathrm{kg}$ for preprocedural sedation and anxiolysis in pediatric patients. It should be used only in hospital or ambulatory care settings, including physicians' and dentists' offices, that are equipped to provide continuous monitoring of respiratory and cardiac function.

\section{References:}

1. J. Zhang, S. Nin, H. Zhang and J.B. Streisand, J Pharm Sci 91 (4) 980-2 (2002)

2. J.J. Horgesheimer, Pediatr. Dent. 23 (6), 491-4 (2001)

3. J.H. Kanto, Pharmacotherapy 5 (3), 138-55 (1985)

4. J. Walker, Accident\&Emergency Nursing. 4 (3), 110-3 (1996)

5. U. Burkhardt, L. Wild L, B. Vetter and D. Olthoff, Anesthesist. 46 (10), 850-5 (1997)

6. C.A. Pywell, YJ. Hung and J. Nagelhout, AANA Journal. 63 (2), 124-130 (1995)

7. W. Tolksdof and C. Eick, Anaethesist vol 40, Jss 12, 661-667 (1991)

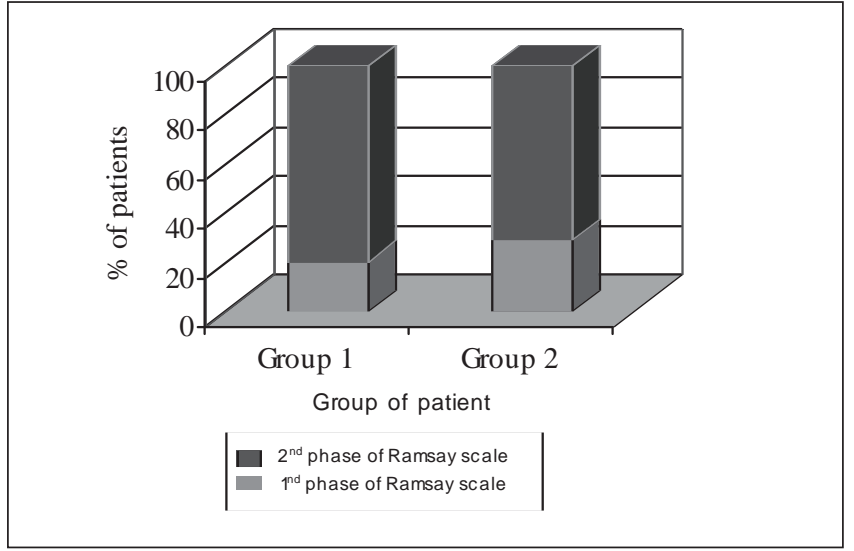

Fig. 1. Sedative efficacy of Midazolam, administered intramuscularly (Group 1) and perorally (Group 2)

8. J. Riva, G. Jejbusiewicz, M. Papa, C. Jauber, W. Kohn and M. Da Fonte, Paediatric Anaesthesia 7 (3), 191-6 (1997)

9. S.I. Steedman, J.R. Koonce, J.E. Wynn and N.H. Brahen, Am. J. Hosp. Pharm. 49 (3), 616-618 (1992)

10. S.E. Walker, H.A. Grad, D.A. Naas and A. Mayer, Anesth. Prog. 44 (1), 17-22 (1997) 


\title{
Резиме \\ Мидазолам сируп, формулација и фармакодинамско дејствување
}

${ }^{1} \mathrm{~K}$. Горачинова, ${ }^{1} \mathrm{~K}$. Младеновска, ${ }^{2} \mathrm{O}$. Гелевска, ${ }^{1}$ Е. Фредро-Кумбараџи, ${ }^{1}$ М. Главаш-Додов, ${ }^{2} \mathrm{~J}$. Нанчева

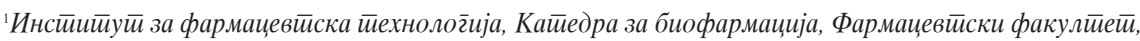 \\ Водњанска 17, 1000 Скойје, Р. Македонија

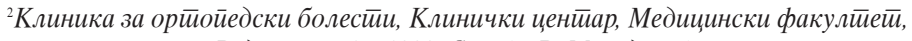 \\ Водњанска 17, 1000, Скойје, Р. Македонија
}

Клучни зборови: мидазолам, сируп, контрола на квалитет, седативен ефект

Мидазоламот како средство за премедикација при хируршки интервенции, болни дијагностички и терапевтски процедури се користи кај пациенти кои припаѓаат на различни возрасни групи. Особено кај педијатриските пациенти е поволна неинвазивна примена при опишаните индикации. Лековитите супстанции наменети за седација инкорпорирани во соодветен дозажен облик треба ефикасно да дејствуваат и да го сведат на минимум негативниот психолошки одговор, физичката нелагодност и болката. Имајќи го ова предвид, како и непостоењето течна дозирана форма/сируп на мидазолам во нашата земја, поставени беа следниве цели: формулирање сируп (преведување на мидазоламот во растворлива форма за постигнување на потребната концентрација во препаратот, при што како сирупна база беше користен воден раствор на средство за зголемување на вискозноста - НРМС, во комбинација со вештачки засладувачи и конзерванси); контрола на квалитетот (физички и физичко-хемиски параметри, микробиолошки квалитет, антимикробна ефикасност на конзервансот, стабилност) и испитување на фармакодинамската ефикасност на сирупот со мидазолам хидрохлорид (следена кај 33 педијатриски пациенти во споредба со ефикасноста на интрамускулно аплицираниот мидазолам хидрохлорид кај 35 пациенти со користење на Ramsay скалата за аналгоседативниот ефект).

Формулацијата покажа задоволителен квалитет во однос на физичките својства, на физичко-хемиските параметри (рН, индекс на рефракција, релативна густина, квантитативна содржина) и микробиолошкиот квалитет во согласност со Ph. Eur. 3. Препаратот е испитуван и стабилен е во текот на четири месеци на ниски температури $\left(2-8^{\circ} \mathrm{C}\right)$ и во услови на втората климатска $30 н а ~\left(26 \pm 0,5^{\circ} \mathrm{C}\right)$. Седативниот ефект по апликацијата на сирупот се јавува во периодот потребен за хируршка премедикација (30-45 минути), постигнувајќи го ефектот на втората фаза на Ramsay скалата во дози од $0,40 \mathrm{mg} / \mathrm{kg}$. 